\title{
Characteristics of Innovations in the Cultivation Process of Intensive Red Chilies
}

\author{
Eva Wardah1*, Setia Budi \\ ${ }^{1}$ Department of Agribusiness, Faculty of Agriculture, Universitas Malikussaleh, Indonesia \\ *Corresponding author: evawardah@unimal.ac.id
}

\section{ARTICLE HISTORY}

Received: 23 June 2019

Revised: 12 August2019

Accepted: 17 September 2019

\section{KEYWORDS}

Cultivation process

Innovation characteristics

Intensive pattern

Red chili

\begin{abstract}
To be able to implement an effective intensive red chili cultivation, the training from related parties are needed by the farmers. The purpose of this study was to determine farmers' assessment of the innovation characteristics of intensive red chili cultivation. The research sample consisted of 32 red chili farmers in MeurahDua District, Pidie Jaya Regency, Indonesia. This research was conducted through a qualitative descriptive approach with data measurement using a Likert scale. Based on farmers' responses to the innovation characteristics of intensive red chili cultivation, the results sequentially showed that the cultivation (1) had a relatively high-profit level, (2) was easy to try, (3) had high suitability level, (4) was observable, and (5) had high level of innovation complexity. The process of red chili cultivation activities included; (1) seed procurement and seeding, (2) land management, (3) planting, (4) plant maintenance, (5) pest and disease control, and (6) harvesting. The role of agricultural extension is greatly needed to continue to provide training and assistance to address problems faced by intensive red chili farmers especially in the selection of superior seeds and good seeding process, balanced fertilization, integrated pest, and disease control.
\end{abstract}

\section{INTRODUCTION}

The earthquake and tsunami wave that struck Aceh Province on December 26, 2004, has raised the spirit to end the conflict that has long affected the people of Aceh. The spirit of peace has also revived the economic enthusiasm of rural communities to carry out agricultural and plantation farming activities. The re-creation of security has become a blessing for the peasants in Pidie Jaya Regency so that they are motivated to create jobs and invest in agriculture. Wossen et al. (2017) believed that "adoption of improved agricultural technologies by smallholders is considered as the main pathway for breaking the poverty trap."

Generally, farmers are the main actors in agricultural development. The success of agricultural development is more determined by the role of the farmers themselves who need guidance and assistance from the government and various related parties. The same thing applies to horticultural crop farmers especially red chili farmers

At present, red chili farmers have indeed received agricultural extension, however, they have not received any intensive training or assistance in the cultivation of intensive red chilies. As a result, the farmers still apply conventional patterns by relying on improper cultivation skills. Therefore, the role of agricultural extension agents is very vital as well as dramatically determines the success in the empowerment of the farming community. Fiaz, Noor, and Aldosri (2016) asserted that agricultural extension agents can better realize the reality and grass-root problems of the farming community and will be in a position to provide feedback to the policymaking institutions, research, and university authorities to ensure the immediate solution for the reported drawbacks.

Red chili (Capsicum annum L) is a horticultural product that is quite strategic for the people of Indonesia. The production of red chilies in Indonesia experienced fluctuations from 2013-2017. The production ranged $1,012,879$ tons, $1,074,602$ tons, $1,045,182$ tons, $1,045,587$ tons, $1,206,266$ tons, respectively. In those years, the productivity of red chili also fluctuated in the range of 8.16 tons/ha, up to 8.60 tons/ha (Ministry of Agriculture, 2018). One of the causes of low agricultural production is due to the attack of plant disturbing organisms (Sembel, 2012).

According to Imran (2008), Agustian and Rahman (2009), from the perspective of cultivation aspects, red chili farming faces various problems such as drought, lack of availability of superior seeds and other input facilities, low skills of farmers, low technology dissemination, low 
intensity of extension, lack of infrastructure, and low price guarantees. These have caused chili production tends to fluctuate.

The chili cultivation business is very feasible to carry out. It is one type of vegetable that has an important role in economic development. Cultivation of this commodity has a bright prospect because it can support efforts to increase farmers' incomes, alleviate poverty and expand employment opportunities.

Red chili cultivation also brings positive impacts on social life, especially in alleviating poverty as well as being a preventive medium for new conflicts in poor as well as conflict-affected communities. It supports Ashrafuzzaman et al. (2011), who asserted that chili pepper is an important spice and cash crop in many countries of the world. For this reason, research on the cultivation of red chilies needs to be carried out for the development of the farming of red chilies in the future.

\section{MATERIALS AND METHODS}

This research was carried out in Meurah Dua District, Pidie Jaya Regency, Indonesia. The population of this research consisted of farmers who conducted intensive chili cultivation with a sample of 32 farmers.

The scope of the study was limited only to find out the innovation characteristics of intensive red chili cultivation technology in the intensive red chili cultivation process. The object of the research consisted of the red chili farmers who provided an assessment of the characteristics of the technology innovation in the red chili cultivation in the process of intensive chili cultivation.

Measurement and analysis of farmers' perceptions of innovation characteristics were conducted by using a Likert scale (Sugiono, 2013) through indicators of innovation characteristics including (1) relative excellence, (2) level of suitability, (3) level of complexity, (4) trialability, and (5) observability.

Analysis of the cultivation process involving indicators of the process of red chili cultivation activities which include(1) seed procurement and seeding, (2) land management, (3) planting, (4) plant maintenance, (5) pest and disease control and (6) harvesting. The results of all these activities are further described in the discussion part of this paper.

\section{RESULTS AND DISCUSSION}

\subsection{Characteristics of Chili Farmers}

Characteristics of chili farmers in this study included: age, formal education level, chili cultivation experience, number of dependents, and land area. A description of the characteristics of red chili farmers is shown in Table 1.

Table 1. Characteristics of Red Chili Farmers

\begin{tabular}{clcccc}
\hline \multirow{2}{*}{ No } & \multicolumn{1}{c}{ Characteristics } & Unit & Low & Range & High \\
\hline 1 & Age & Year & 28 & 64 & 46 \\
2 & Formal education & Formal & 6 & 16 & 8.7 \\
3 & Chili cultivation Experience & Year & 1 & 6 & 4.2 \\
4 & Number of dependents & People & 0 & 7 & 2.9 \\
5 & Land area & Hectare & 0.18 & 1.2 & 0.31 \\
\hline
\end{tabular}

Table 1 shows that the average age of red chili farmers was in the productive age category. According to Sofa (2008), the productive working age in developing countries is 18 to 54 years. At the productive age, farmers are generally able to absorb information quickly and still have a strong physique to carry out agricultural activities. Farmers who are not productive are usually not able to work optimally in processing their farming.

On average, chili farmers went and graduated from junior high school level and are classified as having lower levels of education. Highly educated farmers will adopt innovation and technology more quickly so that they are more dynamic and more efficient at work. However, the low level of formal education was supported by farming experience which averaged 4.2 years. The longer the experience of farming, the easier it is for them to solve farming constraints based on the experience gained in the cultivation of red chili. Rezvanfar, Ghorbanian, and Shafiee (2014) mentioned that higher agricultural education has a huge role in the development of agricultural and employability skills among the students of this field. Davis et al. (2012) also implied that farmer field schools are a useful approach to increase production and income of small-scale farmers.

The average number of family dependents was included in the small category (only three people). The number of dependents greatly affects farming activities. This is because a large number of dependents and is of productive age will contribute to the decreased production costs.

The majority of red chili farmers owned narrow land for intensive red chili cultivation. This was caused by not all land owned by farmers that can be used for intensive red chili cultivation.

\subsection{Characteristics of Intensive Red Chili Cultivation Innovation}

The innovation characteristics of the red chili cultivation technology package in this study included: (1) relative advantages, (2) alignment (compatibility level), (3)complexity, (4) trialability, and (5) observability. In the opinion of farmers, innovation characteristics helped them in deciding whether to apply or reject a technology 
package. The same thing also happened to the cultivation innovations that were delivered to chili farmers. The index value of innovation characteristics based on the view of red chili farmers can be seen in Table 2 .

Table 2. Index Value of Intensive Chili Culture Innovation

Characteristics

\begin{tabular}{rlll}
\hline \multicolumn{1}{c}{ No } & \multicolumn{1}{c}{$\begin{array}{c}\text { Innovation } \\
\text { Characteristics }\end{array}$} & Index (\%) & Interpretation \\
\hline 1 & Relative advantage & 89.06 & Strongly agree \\
\hline 2 & Compability & 70.37 & Agree \\
\hline 3 & Complexity & 47.86 & Not agree \\
\hline 4 & Triability & 72.16 & Agree \\
\hline 5 & Observability & 78.27 & Agree \\
\hline & General Perception & 71.54 & Agree \\
\hline
\end{tabular}

Source: Primary Data analysis, 2019

The results of research on the general assessment of intensive red chili farmers on the characteristics of innovation, especially intensive cultivation of red chili technology at the research location, were in the agreed category. The result shows that the innovation in intensive red chili cultivation provided by extension agents is beneficial for red chili farmers.

Table 2 also shows that the chili farmers perceived the application of intensive chili cultivation technology has a relatively high advantage compared to conventional cultivation systems. The profit obtained might reach 20-22 times higher for one growing season. This affects the total amount of production obtained for each growing season. This is also different from conventional cultivation systems where the frequency of harvesting and production is lower than the intensive chili cultivation pattern.

On the other hand, farmers recognized that intensive cultivation systems require high costs ranging from the provision of superior seeds, land management, planting, maintenance (watering, stamping, fertilizing, integrated pest control), harvesting processes, and post-harvest management. Because of the capital constraints, chili farmers often did not fully apply the intensive chili cultivation package such as the 5T fertilization process (on time, use, dosage, method, and target).

Red chili farmers also believed that the innovation of intensive red chili cultivation is easy to try on a small scale. Most farmers admitted that before applying cultivation on a large scale, they tried cultivation on a small scale. This is in accordance with Agussabti (2002), who stated that farmers more quickly accept innovations that can be tried on a small scale than innovations that cannot be tried first.

Furthermore, the suitability and observability characteristics are in the agreed category where the innovations gave did not conflict with previous farmers' experience even though there are some additional treatments in intensive pattern cultivation activities. In general, intensive chili cultivation technology did not conflict with the values adopted by the red chili farmers at the study site.

The level of complexity of innovation was indeed felt by farmers both in the application of technology such as the application of Black Silver Plastic Mulch, making beds, planting patterns, and the provision of stakes, as well as the time and volume of fertilization. In intensive chili cultivation technology, the rule of organic and inorganic fertilizers is recommended in relatively large amounts compared to what has been applied by farmers so far. Some farmers believed that the condition is not a significant obstacle, although at first, they felt difficulties. However, these difficulties were covered by higher production results compared to previous technology applications.

According to Nyana (2014), the process of controlling pests and diseases in an integrated manner is still an obstacle for farmers, given the variety of pests that attack the cultivation of red chili and also the variety of types of diseases. The development of several types of pests depends on the growing season, namely the rainy season and the dry season.

The complexity felt by farmers in the process of identifying and controlling pests covered dominant pests attacking red chili at the study site including atracnosis, root rot, curly leaves, pest trips (Thrips), leaf caterpillars, fruit flies and aphids that are able to reduce production results by $20-40 \%$ (FAO, 2017). Technical and chemical controls were carried out by farmers to overcome these pests. Farmers also considered that the intensive chili cultivation innovation package is still felt complicated because it has not been supported by sufficient skills of the farmers (Midega et al., 2012).

To support the application of intensive red chili cultivation innovations, farmers were first given training. The results of the initial evaluation and final evaluation of the implementation of intensive red chili cultivation training can be seen in Table 3 .

Table 3. Comparison of Pretest and Post test scores for Intensive

Chili Cultivation Training

\begin{tabular}{clrr}
\hline No & \multicolumn{1}{c}{ Indicative Evaluation } & $\begin{array}{c}\text { Pre test } \\
\text { Score }\end{array}$ & $\begin{array}{c}\text { Post test } \\
\text { Score }\end{array}$ \\
\hline 1 & Processing of chili cultivation land & 40.62 & 81.73 \\
2 & Seed sowing and planting & 47.50 & 79.60 \\
3 & Fertilization & 48.75 & 82.39 \\
4 & Pest and disease control & 39.40 & 67.52 \\
5 & Harvest Implementation & 56,28 & 69.80 \\
\hline
\end{tabular}

Table 3 shows the increase in scores obtained by farmers participating in the training from the initial evaluation to the end of the training. Based on the indicators assessed, there was a change in the behavior of trainees both in terms of cognitive (knowledge) and skills in intensive red chili cultivation. The highest increase occurred in the knowledge and skills of land management for intensive chili cultivation. This is due to the large difference between the treatment of natural and intensive pattern land management systems. In the intense pattern, there are activities in making beds, applying basic fertilizers, and applying mulch plastic. Improved scores also occurred in the way of seed seeding, planting, fertilizing and integrated pest control.

While the least change in behavior was in the 
implementation of harvesting activities where there are differences in how to harvest red chilies cultured naturally and intensively which include timely aspects, techniques, accuracy, and patience. Harvesting too soon will produce less.

Harvesting should be done in the morning after the dew or water runs out from the surface of the fruit skin. Farmers also must avoid the occurrence of damaged and broken branches and twigs during harvesting. Harvested red chilies must also be conducted when they are $80 \%$ red in color. This is an additional input for farmers who have received intensive chili cultivation training.

\section{CONCLUSION}

Most of the red chili farmers were in productive age, had lower levels of formal education, but had long business experience. The number of their dependents was in a small category, and the area of their land for cultivation was in the narrow category.

The characteristics of intensive chili cultivation innovation sequentially were as follows: (1) had a relative advantage when compared to conventional cultivation patterns, (2) the stages of the cultivation process could be observed, (3) The innovation could be tried on a small scale to ensure the success of the innovation of red chili cultivation (4) suitability with the support of land natural resources and did not conflict with experience and values held by the farmers (5) had a level of complexity at the beginning of the process of applying cultivation related to the skills of intensive red chili cultivation.

This research recommends that the government through the extension apparatus, to keep providing continuous training and assistance to farmers to address the problems faced in intensive red chilies, especially balanced fertilization skills, integrated pest, and disease control.

\section{REFERENCES}

Agustian, Adang, \& Rachman, Benny. (2009). Penerapan teknologi pengendalian hama terpadu pada komoditas perkebunan rakyat. Perspektif,8(1): 30-4I.

Agussabti. (2002). The Farmers Autonomy in the Adoption of Innovation Decision-Making (The Case of Vegetable Farmers in West Java Province). Bogor: Unpublished Dissertation of IPB University.

Ashrafuzzaman, M., Halim, M. Abdul., Ismail, Mohd Razi., Shahidullah, S.M., and Hossain, M. Alamgir. (2011). Effect of Plastic Mulch on Growth and Yield of Chili (Capsicum annum L). Brazilian Archives of Biology and Technology, 54 (2): 321-330.

Davis, K., Nkonya, E., Kato, E., Mekonnen, D.A., Odendo, M., Miiro, R., \& Nkuba, J. (2012). Impact of Farmer Field Schools on Agricultural Productivity and Poverty in East Africa.World Development, 40(2): 402-413.

Fiaz, Sajid., Noor, Mehmood Ali.,\& Aldosri, Fahad Owis. (2016). Achieving food security in the Kingdom of Saudi Arabia through innovation: Potential role of agricultural extension. Journal of the Saudi Society of Agricultural Sciences.

Kementan. (2018). StatistikPertanian 2018. Jakarta (ID): Kementan.

Midega, C. A, et al. 2012.Farmers' perceptions of cotton pests and their management in western Kenya.Crop Prot,42:193-201.

Nyana, D. (2014). Pengendalian Penyakit Virus pada Tanaman Cabai dengan Teknik Ramah Lingkungan. Laporan Penelitian. LPPM,
Universitas Udayana.

Nauly, Dahlia. (2016). Fluctuation and price disparity of chili in Indonesia. Jurnal Agrosains dan Teknologi Fakultas Pertanian Universitas Muhammadiyah Jakarta, 1, (1): 56-69.

Rezvanfar, Ahmad., Ghorbanian, Maria., \& Shafiee, Fatemeh. (2014). An investigation of the behaviour of agricultural extension and education engineering students in Tehran University towards employability. Procedia - Social and Behavioral Sciences, 152, 65-69.

Rogers. E. M and F. Shomaker. (1983). Diffusion of Innovation (3rd edition). The Free Press: A. Division Of Macmillan. Publishing. Co.Inc.New York.

Sugiyono. (2013). Metode Penelitian Kombinasi (Mixed Methods). Bandung (ID): Alfabeta.

Wossen, Tesfamicheal., Abdoulaye, Tahirou., Alene, Arega., Haile, Mekbib G., Feleke, Shiferaw., Olanrewaju, Adetunji., \& Manyong, Victor. (2017). Impacts of extension access and cooperative membership on technology adoption and household welfare. Journal of Rural Studies 54, 223-233. 